\title{
HeRO
}

\section{(Hemodialysis Reliable Outflow) graft alkalmazása tartós hemodialíziskezelés során}

\author{
Legeza Péter dr. - Garbaisz Dávid dr. \\ Szeberin Zoltán dr. - Sótonyi Péter dr.
}

Semmelweis Egyetem, Általános Orvostudományi Kar, Városmajori Szív- és Érgyógyászati Klinika, Budapest

\begin{abstract}
A végstádiumú veseelégtelen betegek kezelésének folyamatos fejlődése és túlélési eredményeinek javulása következtében egyre nagyobb kihívást jelent tartós, jól múködő arteriovenosus összeköttetés létrehozása. A HeRO (Hemodialysis Reliable Outflow) rendszer lehetővé teszi megfelelően funkcionáló arteriovenosus sönt képzését olyan betegekben, akiknél mindkét oldali centrális vénás elzáródás miatt felső végtagi sönt készítése már nem jönne szóba. Hazánkban először ültettünk be eredményesen HeRO graftot egy tartós hemodialízisben részesülő betegnél. Célunk az ezzel kapcsolatos tapasztalataink bemutatása. Esetismertetésünkben a betegdokumentációt, a pre- és posztoperatív képalkotó vizsgálatokat tekintettük át. Betegünk (73 éves nő) 12 éve részesül rendszeres hemodialíziskezelésben. Mindkét felső végtagon számos alkalommal történt arteriovenosus fistula létrehozása, fistulathrombectomia, valamint mindkét oldalon sor került tartós tunelizált dialíziskanül használatára. Bal oldali könyöktáji fistulájának elzáródását követôen konvencionális sönt képzése nem jött szóba a mindkét oldalon kialakult vena subclavia occlusióra tekintettel, ezért HeRO graft implantációja mellett döntöttünk. A sikeres graftimplantációt követően 7, majd 12 hónappal történt graftthrombectomia és endovascularis intervenció, melyet követően ismét jó hatásfokú hemodialízis végezhető a grafton keresztül. A mindkét oldali felső testfél centrálisvéna-occlusiója esetén a HeRO graftrendszer megfelelő alternatívája lehet a tunelizált dialíziskanülöknek és alsó végtagi arteriovenosus összeköttetéseknek.
\end{abstract}

Orv Hetil. 2019; 160(31). 1231-1234.

Kulcsszavak: hemodialízis, HeRO graft, centrálisvéna-stenosis, végstádiumú veseelégtelenség

\section{The use of HeRO (Hemodialysis Reliable Outflow) graft in hemodialysis}

Creating durable vascular access has become more complicated with the improvement of the management and with the increasing survival of patients with end-stage renal disease. HeRO (Hemodialysis Reliable Outflow) graft allows to maintain vascular access on the upper limb in patients with the presence of bilateral central venous occlusion. Our institute was the first in Hungary to perform a HeRO graft implantation in a patient receiving regular hemodialysis. Our objective was to present our findings with this recent innovation. Case report, medical documentation and imaging studies were reviewed. The patient (73-year-old, female) has been receiving hemodialysis since 12 years with the history of several arteriovenous fistula (AVF) creations, thrombectomies, use of central venous catheter in both sides. Following the occlusion of a left cubital arterio-venous fistula, none of the conventional vascular access types could have been performed due to bilateral subclavian vein occlusion. Successful HeRO graft implantation was performed. The patient underwent graft thrombectomy and endovascular intervention 7 and 12 months after the original procedure. After both reoperations, the graft functioned well for hemodialysis. HeRO graft can be a good alternative to central venous catheters and lower limb arterio-venous grafts in cases of bilateral central venous occlusion.

Keywords: hemodialysis, HeRO graft, central venous stenosis, end-stage renal failure

Legeza P, Garbaisz D, Szeberin Z, Sótonyi P. [The use of HeRO (Hemodialysis Reliable Outflow) graft in hemodialysis]. Orv Hetil. 2019; 160(31): 1231-1234.

(Beérkezett: 2019. február 14.; elfogadva: 2019. február 25.) 


\section{Rövidítések}

$\mathrm{AV}=$ arteriovenosus; $\mathrm{BMI}=($ body mass index $)$ testtömegindex $;$ COPD $=($ chronic obstructive pulmonary disease $)$ krónikus obstruktív tüdőbetegség; $\mathrm{CV}=$ centrális véna; $\mathrm{CVK}=$ centrális vénás katéter; $\mathrm{ePTFE}=$ (expanded polytetrafluoroethylene $)$ kiterjesztett poli(tetrafluor-etilén $) ; \mathrm{Fr}=($ french $)$ mértékegység (katéterátmérő); HD = hemodialízis; HeRO = Hemodialysis Reliable Outflow; PTA = percutan transluminalis angioplastica; TDK = tartós dialíziskanül

A krónikus veseelégtelenség miatt vesepótló kezelést igénylő betegek száma évről évre folyamatos növekedést mutat, ami az öregedő társadalomnak, a II-es típusú cukorbetegség növekvő incidenciájának és a nephrotoxicus gyógyszerek elterjedésének következménye [1]. A hemodialízis (HD)-kezelésben részesüló betegek társbetegségei, valamint átlagéletkoruk és a tartós HD-kezelés mellett eltelt idő hosszának növekedése, a többszöri endovascularis és sebészi intervenciók miatt egyre nagyobb mértékben válnak szükségessé összetettebb mútéti beavatkozások a megfelelően funkcionáló arteriovenosus (AV) összeköttetés létrehozására és fenntartására.

Igen ritka, de a betegek életkilátásainak javulásával egyre gyakrabban előforduló esetet jelent, amikor mindkét oldali felső testfél CV súlyos stenosisa vagy occlusiója áll fenn. A kétoldali CV-elzáródás előfordulásának lehetőségét jelentősen növeli, ha az anamnézisben már mindkét oldalon ideiglenes és állandó dializálókatéterek beültetése szerepel. Tovább fokozza a rizikót, ha korábban kanülinfekció is kialakult. Ezekben a hagyományos felső végtagi AV összeköttetés képzésére alkalmatlan betegekben az alsó végtagi vagy tunelizált dialíziskatéterek (TDK) alternatívája lehet a Hemodialysis Reliable Outflow (HeRO) graft (1. ábra). Az eszköz egy $6 \mathrm{~mm}$ átmérójü, titániumcsatlakozóval ellátott „expanded” (kiterjesztett) poli(tetrafluor-etilén) (ePTFE) graftkomponensből, valamint a vénás elfolyást biztosító $19 \mathrm{Fr}$-es szilikonkatéterből áll. A rendszer segítségével HD-re használható AV összeköttetést hozunk létre az arteria brachialis és a jobb pitvar között [2].

Habár az Egyesült Államokban a HeRO graftrendszer 2008 óta engedélyezett, Európában csak néhány éve került bevezetésre. Hazánkban először klinikánkon került sor HeRO graft beültetésére, mellyel kapcsolatos tapasztalatainkat mutatjuk be cikkünkben (1. ábra).

\section{Esetismertetés}

Betegünknek (73 éves nő) 15 éve ismert a krónikus veseelégtelensége, mely miatt 12 éve rendszeres HD-kezelésben részesül. Anamnézisében COPD, túlsúly (BMI: $\left.30 \mathrm{~kg} / \mathrm{m}^{2}\right)$ szerepel. Mindkét felső végtagon képzett csuklótáji radiocephalicus (Brescia-Cimino-) fistula, könyöktáji radiocephalicus AV fistula, mindkét oldali brachiobasilicus transpositio, az utóbbiak közül a jobb oldalinak thrombectomiája, reanasztomózisa, majd ane-

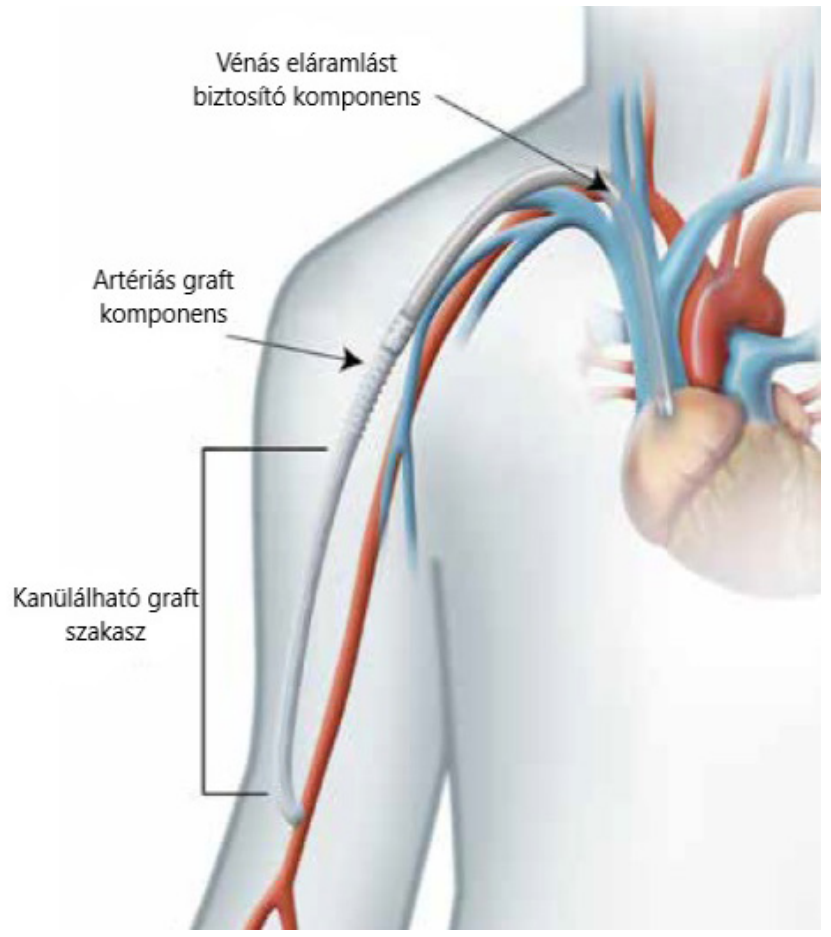

1. ábra

Jobb oldali Hemodialysis Reliable Outflow (HeRO), kiterjesz tett poli(tetrafluor-etilén) (ePTFE)

urizmaképződés miatt reszekciója szerepel. Emellett több alkalommal esett át fistula-vénásszár percutan transluminalis angioplasticán (PTA). Fistulamútétjei között többször szorult centrális vénás katéter $(\mathrm{CVK})$ behelyezésére. Ismert bal oldali vena (v.) subclavia occlusiója mellett cubitalis AV fistulája évekig funkcionált vállövi és intercostalis kollaterálisoknak köszönhetôen, azonban aneurizmatikus tágulat, thrombusképződés miatt végzett aneurizmareszekciót és reanasztomózist követően ez a fistula is elzáródott. A v. subclavia rekanalizációs kísérletére két alkalommal került sor, ezek azonban sikertelennek bizonyultak, ezért a továbbiakban HD-kezelése bal oldali, v. jugularisba vezetett TESIO kanülön keresztül történt.

Tekintettel a mindkét oldali ismert v. subclavia occlusióra, valamint a többszörös felső végtagi operációkra, konvencionális sönt képzése nem jött szóba. Mivel a centrális vénák PTA-ja több kísérlet kapcsán is sikertelennek bizonyult, jobb oldali HeRO graft implantációja mellett döntöttünk.

A mútét során a jobb v. jugularis ultrahangvezérelt punkciója történt a mellkasbemenethez közel. A HeRO graft szilikonkatéterét Seldinger-féle technikával percutan, a jobb v. jugularis internán keresztül vezettük a v. cava superior és a jobb pitvar határáig röntgenkép-erősítő ellenőrzése mellett. A sulcus deltoideopectoralisban ejtett hosszanti metszésen keresztül a kanült a nyaki sebből a váll fölötti sebbe húztuk át. A HeRO rendszer ePTFE-szárát a titáncsatlakoztatókkal a kanülhöz kapcsoltuk, majd a felkar alsó harmadában, medialis oldalon ejtett metszéshez vezettük subcutan képzett csatornán 
keresztül (2. ábra). Tekintettel a felkar felső harmadában, magasan oszló arteria (a.) brachialisra, az ePTFEgraftot az a. axillarishoz vég az oldalhoz anasztomizáltuk, ezáltal egy hurkot (loop) képezve a hemodialíziskezeléshez (3. ábra). A HeRO graft ePTFE-szakaszát a beavatkozást követően 5 héttel kezdték el szúrni hemodialíziskezelés céljából. A mútét során amoxicillin-klavulánsav antibiotikumprofilaxist alkalmaztunk. A beavatkozást követően 2 hónappal eltávolították a bal oldali v. jugularisból a TDK-t (2. és 3. ábra).

A primer mütétet követően 8 hónappal a graft occlusiója miatt thrombectomiát, majd a graft kanül előtti szakaszán található szúkület ballonos tágítását és sztent implantációját végeztük. Ezt követően a graft ismét HDkezelésre alkalmassá vált. A posztoperatív 12. hónapban ismételt graftocclusio miatt thrombectomia és a graft distalis ívének ballonos tágítása történt, melyet követően a fistula ismét használhatóvá vált. Jelenleg 13 hónapos követésnél a fistulán keresztül továbbra is jó hatásfokkal végezhető HD-kezelés.

\section{Megbeszélés}

Arteriovenosus összeköttetés kialakításakor az első választandó mütéti megoldás a felső végtagi, minél distalisabb, autológ módon létrehozott AV fistula. Prosztetikus graft beültetése magasabb fertőzéses rizikóval és rosszabb nyitvamaradási eredményekkel jár, ami miatt alkalmazásukra csak autológ fistulaképzés lehetőségének hiányában kerülhet sor $[3,4]$.

Centrálisvéna-elzáródás esetén a vénás elfolyási akadály megszüntetése nélkül a klasszikus felső végtagi arte-

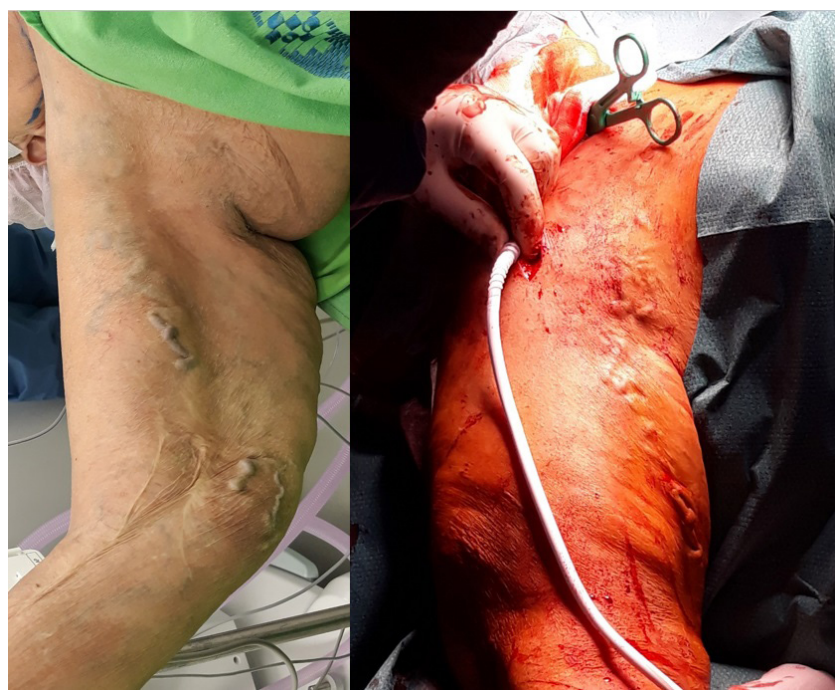

2. ábra

Pre- és intraoperatív képek. Bal oldalon: többszörös felső végtagi fistulaképzések gyógyult hegei, valamint tágult vénás kollaterális rendszer a felkaron és a hónaljárokban. Jobb oldalon segédmetszés a felkar proximális harmadán a HeRO graft komponenseinek összekapcsolásához, valamint az ePTFE-komponens tervezett lefutása

ePTFE $=$ kiterjesztett poli(tetrafluor-etilén $) ; \mathrm{HeRO}=\mathrm{Hemo}$ dialysis Reliable Outflow

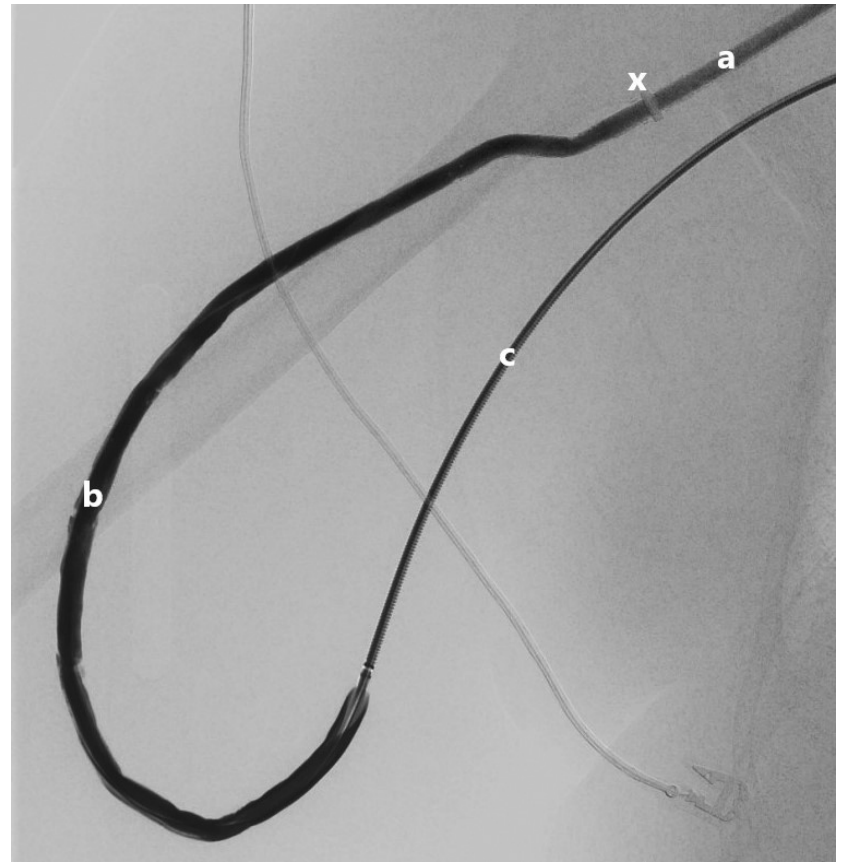

3. ábra DSA-kép a loop-graftként vezetett HeRO graftról; a) szilikon-
katéter; b) ePTFE-loop; c) a. brachialisba vezetett angiographi-
ás katéter; x: titániumcsatlakozó
DSA = digitális szubtrakciós angiográfia; HeRO = Hemodialysis
Reliable Outflow

riovenosus összeköttetések nem alkalmazhatók. Ezekben az esetekben alsó végtagi AV összeköttetés készítése vagy TDK behelyezése jön szóba. A vérnyerési lehetőségek teljes kimerülése esetén bonyolult mütéti megoldások jöhetnek csak szóba. Ezek közé olyan, magas morbiditású és mortalitású beavatkozások tartoznak, mint a nyaki (axillojugularis bypass) vagy a mellkas megnyitásával járó (axillocavalis, axilloatrialis) bypassmütétek $[5,6]$.

TDK-n keresztül dializált betegeknél a véráramfertőzés és a katéter elzáródása magasabb morbiditást és mortalitást okoz. Danese és mtsai a TDK-t használó betegek között 34\%-os, infekcióasszociált mortalitást írtak le [7].

A HeRO graft új, innovatív módszer; indikációját kifejezetten a mindkét oldali CV súlyos stenosisa vagy occlusiója jelenti, melynek endovascularis rekonstrukciója nem lehetséges. A kétkomponensü, ePTFE-graftból és szilikonkatéterből álló rendszer artériás beáramlását az a. brachialis adja, a vénás eláramlást a szív jobb pitvara biztosítja. Kiterjesztett nyaki feltárással vagy mellkasmegnyitással nem jár. A centrális része percutan bevezethető, és a distalis rész sebészi beültetése sem jár jelentős mútéti megterheléssel. Ennek köszönhetően a CV-occlusio teljesen subcutan módon kerül „áthidalásra”, és a TDKekkel ellentétben nincs a külvilággal direkt összeköttetése a rendszernek [2].

A HeRO graft egyéves elsődleges és másodlagos nyitvamaradási ideje a natív fistuláknál és az AV graftoknál rosszabb, fontos azonban megjegyezni, hogy a HeROgraft-implantációra kerülő betegek szelektált betegcsoportot alkotnak, akár több alkalommal elzáródott AV 
összeköttetéssel a kórtörténetükben. Az alsó végtagi AV graftokkal összehasonlítva a HeRO graft nyitvamaradása közel megegyező eredményeket mutatott, ami mellett az infekciók előfordulása ritkább volt a HeRO-implantáción átesett csoportban [8]. Az Al Shakarchi és mtsai által végzett vizsgálat alapján a HeRO grafthoz asszociált infekciók aránya szignifikánsan alacsonyabb a TDK-használathoz köthető infekciókénál [9].

\section{Következtetés}

Hazánkban elsőként sikeresen ültettünk be HeRO graftot. A HeRO graft az eddigi tapasztalatok alapján megfelelő alternatívája lehet a tunelizált dialíziskatétereknek, így mindkét oldali centrális vénás occlusio esetén, magas mútéti kockázatú betegeknél vagy bonyolult anatómiai helyzetben (kifejezett obesitas, többször operált terület stb.) alkalmazása mérlegelendő. A HeRO graft beültetéséhez a nyitott és endovascularis hibrid mútéti technológiában jártas érsebészi háttér és megfelelő mưtői körülmények elengedhetetlenek.

Anyagi támogatás: A szerzők anyagi támogatásban nem részesültek.

Szerzôi munkamegosztás: L. P.: A betegdokumentáció áttekintése, a kézirat megírása. G. D.: Részvétel a kézirat elkészítésében. Sz. Z., S. P: Az operáció elvégzése, segítség a kézirat megírásában. A cikk végleges változatát valamennyi szerző elolvasta és jóváhagyta.

Érdekeltségek: A szerzőknek nincsenek érdekeltségeik.

\section{Irodalom}

[1] Port FK. End-stage renal disease: magnitude of the problem, prognosis of future trends and possible solutions. Kidney Int Suppl. 1995; 50: S3-S6.

[2] Katzman HE, McLafferty RB, Ross JR, et al. Initial experience and outcome of a new hemodialysis access device for catheterdependent patients. J Vasc Surg. 2009; 50: 600-607.el.

[3] Schmidli J, Widmer MK, Basile C, et al. Editor's choice - vascular access: 2018 Clinical Practice Guidelines of the European Society for Vascular Surgery. Eur J Vasc Endovasc Surg. 2018; 55: 757-818.

[4] Murad MH, Elamin MB, Sidawy AN, et al. Autogenous versus prosthetic vascular access for hemodialysis: a systematic review and meta-analysis. J Vasc Surg. 2008; 48(5 Suppl): 34S-47S.

[5] Jakimowicz T, Galazka Z, Grochowiecki T, et al. Vascular access for haemodialysis in patients with central vein thrombosis. Eur J Vasc Endovasc Surg. 2011; 42: 842-849.

[6] Duncan JM, Baldwin RT, Caralis JP, et al. Subclavian vein-toright atrial bypass for symptomatic venous hypertension. Ann Thorac Surg. 1991; 52: 1342-1343.

[7] Danese MD, Griffiths RI, Dylan M, et al. Mortality differences among organisms causing septicemia in hemodialysis patients. Hemodial Int. 2006; 10: 56-62.

[8] Kudlaty EA, Pan J, Allemang MT, et al. The end stage of dialysis access: femoral graft or HeRO vascular access device. Ann Vasc Surg. 2015; 29: 90-97.

[9] Al Shakarchi J, Houston JG, Jones RG, et al. A review on the Hemodialysis Reliable Outflow (HeRO) graft for haemodialysis vascular access. Eur J Vasc Endovasc Surg. 2015; 50: 108-113.

(Legeza Péter dr., Budapest, Városmajor u. 68., 1122 e-mail: peterlegeza@gmail.com)

\section{„Varietas delectat." (Cicero) \\ (A változatosság gyönyörködtet.)}

\footnotetext{
A cikk a Creative Commons Attribution 4.0 International License (https://creativecommons.org/licenses/by/4.0/) feltételei szerint publikált Open Access közlemény, melynek szellemében a cikk bármilyen médiumban szabadon felhasználható, megosztható és újraközölhetö, feltéve, hogy az eredeti szerző és a közlés helye, illetve a CC License linkje és az esetlegesen végrehajtott módositások feltüntetésre kerülnek. (SID_1)
} 